\title{
FARMING ON THE FOOTHILL PROPERTY OF MR F. J. MEYER
}

\author{
By A. C. Meyer
}

: This property, which is farmed by my brother and myself, is on the Claremont silt loam soil type at an altitude. of $450 \mathrm{ft}$. and our rainfall averages 34 to $36 \mathrm{in}$. annually. The area of the farm is 1423 acres, all of which is ploughable, with the exception of steep back faces and gullies, with 716 acres one side and 707 acres' the other side of the road which bisects the property. The history of the farming of this property as a single unit dates from 1945, as before that we ran the place in conjunction with 250 acres of heavy land at Studholme.

The general improvement of the place began with the growing of fairly large areas of swedes and turnips not only for our own winter feed but also to allow us to sell some surplus winter feed for cash. This gave us a sizeable area to sow out to grass each year, for in 7 years we have sown out 908 acres of new grass. The rotation is a simple one, being the breaking up of about 100 to 140 acres of old grass for ridged swedes and turnips and sowing it down again in the next year under rape. Only. llb. per acre of rape seed is used and is sown in 14in. rows; the grass seed mixture is broadcast. This amount of rape is sufficient to fatten all our wether lambs and sometimes we are able to fatten bought-in lambs as well.

Our swedes and turnips are ridged with 3cwt. per acre of reverted superphosphate and a further $21 \mathrm{cwt}$. per acre of reverted superphosphate is used when sowing out our new grass with rape. So far we have not used any further superphosphate as topdressing for pastures. This country has responded very well to liming and it is our practice to sow 200 to 300 tons of lime each year. We claim that every ton of lime 'sown has increased our flock by one ewe.

The grass seed mixture generally sown is:-

251b. of 90 per cent. equivalent Mother perennial 'ryegrass.

$\mathbf{K}$

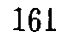


$2 \frac{1}{2} \mathrm{lb}$. to $31 \mathrm{~b}$. of Montgomery red clover.

$21 \mathrm{~b}$. to $31 \mathrm{~b}$. of Mother seed white clover.

$61 \mathrm{~b}$. to 8lb. of cocksfoot.

1lb. to $21 \mathrm{~b}$. of crested dogstail.

The mixture is varied at times, particularly in paddocks where we wish to save seed, for it has been our practice to harvest not only our own requirements of ryegrass, white clover, and Montgomery red clover, but also our cocksfoot requirements from an 8-acre stand which we had in for some years. We do not use it all and have saleable surpluses of seed;

We started with 1400 ewes in 1945 and some 60 cattle. These numbers have been gradually increased as follows:-

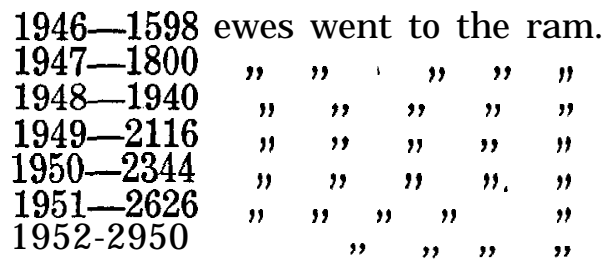

This is an increase'bf 1550 ewes in 7 years. At the moment we have about 300 cattle comprising 70 cows with calves at foot, 120 yearlings, and 402 -year-old steers and-heifers.

The ewe flock is straight Romney and all ewes are mated to Romney rams. We practise pre-lamb shearing, usually about 23 August, and lambing commences on or about 10 September. Our lambing percentage is not yet high, being 90 per cent. to 95 per cent., but we put this down to the large proportion of 2-tooth ewes in the flock. We do not look for any fat lambs off the mothers, so all the wether lambs are fattened on rape. These go away at an average weight of $36-371 \mathrm{~b}$. and when we have a surplus of rape, as was the case last year, we fattened our 1100 wether lambs and 700 bought-in lambs as well, with only a tail-end of 60 to 70 .

All the ewe lambs are carried forward and out of the 1150 ewe hoggets on the place at the moment, about 850 will go into the flock as 2 -tooths and the balance will be sold at the local ewe fair. The ewe flock is culled for age and an annual draft of about 300 to 4005 -year-old ewes are disposed of at the annual ewe fair; Ewe losses throughout the year amount to 3 to 4 per cent.

The labour required to run this property is 4 men, 